\title{
Performance of certain herbicides under two sources of nitrogen fertilization on broomrape growth and cabbage crop. Ghalwash, A. M. ${ }^{1}$; Azza E. A. khaffagy ${ }^{1}$; R. A. Mousa. ${ }^{1}$ and A.S.A. Gendy ${ }^{2}$ ${ }^{1}$ Weed Research Central Laboratory, Agric. Res. Center, Giza, Egypt. ${ }^{2}$ Research Institute of Horticultural Crops, Agric. Res. Center, Giza, Egypt.
}

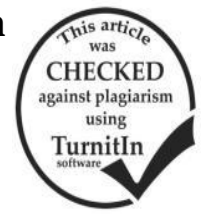

\section{ABSTRACT}

Two experiments were conducted on cabbage at the wire - house in Weed Research Section, at Sakha Agricultural Research Station, Kafr - El-Sheikh Governorate during 2009/10 and 2010/11 seasons. The objective of the present study was to investigate, the efficacy of some herbicides on controlling broomrape as parasite weed under two sources of mineral nitrogen fertilization (ammonium sulfate and ammonium nitrate). The cabbage cultivar, Brunzwick, was used. Broomrape control treatments were Bendimethalin at 750 ga.i./fed., incorporation in soil, Glyphosate at $36 \mathrm{~g} / \mathrm{a} . \mathrm{i} / \mathrm{fed}$., Imazapic at $20 \mathrm{~g} / \mathrm{a} . \mathrm{i} / \mathrm{fed}$. twice, hand pulling twice, and weedy check. Results indicated that ammonium sulfate decreased number and weight of broomrape spikes/m², spikes length and number of capsules/spikes, during 2009/10 and 2010/11 seasons, but increased cabbage yield (7.3 and 6.4\%), as compared with ammonium nitrate during both seasons. Results also showed that all broomrape control treatments exerted significant efficiency in controlling broomrape: Imazapic twice, gave the best broomrape control and the highest increase in cabbage yield and quality, followed by Glyphosate, and hand pulling, twice. Thus, the herbicides Imazapic and Glyphosate decreased number and weight of broomrape spikes $/ \mathrm{m}^{2}$, spikes length and number of capsules/spike. Also, all tested herbicides gave the highest significant increase in the head quality characters in cabbage. The best treatments for increasing the number and weight of edible leaves were Glyphosate, Imazapic and hand pulling, twice; the highest head quality was obtained by Glyphosate and Imazapic; while the highest increase in head characteristics was observed by the hand pulling, twice, Glyphosate and imazapic treatments. Yield increases were estimated by 85.7, 73.1 and $62.1 \%$, respectively in first season and by $65.4,83.8$ and $49.1 \%$, in second one, respectively from Glyphosate, Imazapic and hand pulling, twice Glyphosate, Imazapic and hand pulling twice as compared with weedy check. Thus, these herbicides treatments can replace hand pulling for controlling broomrape weed in cabbage crop.

Keywords: Orobanche, Fertilization, Cabbage, Broomrape, Weed Control.

\section{INTRODUCTION}

Most of the vegetable crops are considered to be extremely poor competitor against weeds under field conditions. The branched broomrape is an obligate root parasite of many economically important dicotyledonous crops such as tomato, tobacco, potato, eggplant, carrot, mustard and sunflower. Within the last 15 years, John Nalewaja and Matysiak (1992) stated that nitrogen fertilizer have been more frequency added to the spray solution as an adjuvant to increase herbicide activity. Ammonium sulfate (NH4) appears to be the active component of these fertilizer solutions and has improved the performance consistency on some weeds. It is still unclear how ammonium sulfate improves herbicide performance. Hence, ammonium nitrate, ammonium sulfate and urea at $207 \mathrm{~kg} \mathrm{~N} / \mathrm{ha}$ were the optimum level in controlling branched broomrape. Round up (glyphosate) is one product that specifically recommends on its label the addition of ammonium sulfate or a higher rate of round up for hard water, cool air temperature or drought conditions. Curran et al. (2014) reported that herbicides that appear to benefit from the addition of ammonium are relatively polar, weak acid herbicides such as basagran, sulfonylureas and imidazolinons. Americanos and Vouzounis (1995) found that the parasite was effectively controlled in the field by spraying twice with glyphosate at 60 to $100 \mathrm{~g}$ a.i./ha or imazaquin at 5$10 \mathrm{~g}$ a.i./ha. Some evidences, from pot experiments suggested that trifluralin at $0.9 \mathrm{~kg}$ a.i./ha may have a beneficial effect in reducing Orobanche infestation. Garcia Torres et al. (1995) showed that imazapic, applied post once at 10 to $15 \mathrm{~g} / \mathrm{ha}$ on sunflower plants with 12 to 19 leaves effectively controlled sunflower broomrape without crop damage. Al-Rahban et al. (2009) found that the application of imazapic resulted in high level of Orobanche control up to $84.0 \%$ and $86.0 \%$ in both Idleb and Aleppo sites, respectively. Lentil seed yield was also increased by $100 \%$ and $109.0 \%$ at the above-mentioned locations, respectively. Etagegnehu and Rungsit (2004) reveled that urea at 276 and $207 \mathrm{~kg} \mathrm{~N} / \mathrm{ha}$ ammonium nitrate, and ammonium sulfate at $207 \mathrm{~kg} \mathrm{~N} / \mathrm{ha}$ and the goat manure at 20 and 30 t/ha were found to be most effective in reducing parasitism and enhancing growth of tomato plants. Even though drastic reduction of branched broomrape infestation was obtained, ammonium nitrate and ammonium sulfate at $276 \mathrm{~kg} \mathrm{~N} / \mathrm{ha}$ seemed to be injurious to tomato plants. As nitrogen rates increased, the numbers and dry weights of shoot of branched broomrape decreased and the yields of tomato increased linearly except the yields obtained from the highest rate of ammonium nitrate and ammonium sulfate. This result indicated that branched broomrape infestation of tomato was decreased with increases of soil nitrogen. Dixit et al. (2005) and Sonnenberg and Silva (2005) cited that the plants of plots weeded once (one month after transplanting) and twice (one and 2 months after transplanting) were significantly earlier than those weeded only once ( 2 months after transplanting) or no weeded. Semidey et al . (1999) stated that the oxyfluorfen at $0.16 \mathrm{~kg}$ a.i./ha, pendimethalin at $0.75 \mathrm{~kg}$ a.i./ha and metribuzin at $0.70 \mathrm{~kg}$ a.i./ha significantly reduced the weed population and dry weight accumulation at 45 days after transplanting cabbage and increased the cabbage yield above that of the untreated control. Dhiman et al. (2005) found that pendimethalin at $1.0 \mathrm{~kg}$ ha- 1 resulted in the highest number of total cabbage heads per plot $(26.67 \mathrm{~kg})$, 
marketable heads per plot $(18.83 \mathrm{~kg})$, average head weight $(0.632 \mathrm{~kg})$, marketable yield $(141.97 \mathrm{q} / \mathrm{ha})$ and thus, the maximum returns (Rs. 26 517) per hectare. Caruso et al. (2000) found that the highest cabbage yield (26 t/ha-1) was obtained by herbicide treatment i.e. chlorthal- dimethyl $(3.4 \mathrm{~kg} / \mathrm{ha})+$ propachlor $(3.2$ $\mathrm{kg} / \mathrm{ha}$ ) and no weed control) Neumann et al. (1999) cited that the fact that hydroxyproline -rich glycoprotein (H R G P) accumulation at the host side of the interface support the view of. At last, a partial defense reaction in the invaded host root tissues within houstoria. H R G P were restricted to differentiating xylem elements, implying a spatio-temporal regulation of H R G P in developmental processes.

\section{MATERIALS AND METHODS}

The present research work was carried out in the wire- house, Sakha Agricultural Research Station, Kafr El- Sheikh Governorate during 2009/10 and 2010/11 winter seasons. This study aimed to investigate the performance certain herbicides treatments under sources of nitrogen fertilization (ammonium sulfate and ammonium nitrate) on broomrape (Orbanche ramosa, Forsk.) control and cabbage crop (Brassica Oleracea var Capitata).

The soils of the two experiments were clay textured. Determination of soluble cations and onions and available N,P and K was done according to Jackson ( 1967). Soil pH was achieved in a 1: 2.5 soil- water suspension according to Black et al (1965).

Table a. Soil mechanical and chemical analyses of the experimental sites in $2009 / 10$ and 210/11 seasons.

\begin{tabular}{lccc}
\hline \multicolumn{2}{l}{ Soil analysis } & 2010 season & 2011 season \\
\hline Sand $\quad(\%)$ & 16.70 & 18.90 \\
Silt $\quad(\%)$ & 33.14 & 32.73 \\
Clay $\quad(\%)$ & 50.20 & 48.40 \\
Soil textural class & Clay & Clay \\
pH (1:2.5 soil :water extraect) & 8.00 & 8.09 \\
Soil salts E.C.(m.mhos/cm) & 2.49 & 3.01 \\
Organic matter (\%) & 1.54 & 1.30 \\
Available nitrogen (ppm) & 19.35 & 22.00 \\
Available phosphorus (ppm) & 15.00 & 20.00 \\
Available potasium (ppm) & 278.1 & 283.00 \\
\hline
\end{tabular}

Treatments of each experiment were arranged in a split plot design with four replicates. The main plot area was $10.5 \mathrm{~m}^{2}$ which contains five rows. Each row was of 3.5 meter in length and $60 \mathrm{~cm}$ apart. The treatments were as follow:

\section{Main plots (N sources):}

1. Ammonium nitrate $(33.5 \% \mathrm{~N})$ which added at rate of $100 \mathrm{~kg} / \mathrm{fed}$.

2. Ammonium sulfate $(21 \% \mathrm{~N})$ which added at rate of $160 \mathrm{~kg} / \mathrm{fed}$.

Sub-plots (herbicides treatments):

3. Stomp (Pendimethalin50\% CS) $N$-(1-ethylpropyl)3,4-dimethyl-2,6- dinitrobenzenamine ) at rate of $750 \mathrm{~g}$ a.i./fed. which used through incorporation in soil before transplanting.
4. Round up (Glyphosate $48 \%$ WSC) N(phosphonomethyl glycine) at rate of 36 g. a. i /fed. applied twice, at 40 days after transplanting and 21days later.

5. Orban (Imazapic 10\%SL) ( \pm )-2-[4,5-dihydro-4methyl-4-(1-methylethyl)-5-oxo- $1 H$-imidazol-2-yl]5-methyl-3-pyridinecarboxylic acid) at rate of $20 \mathrm{~g}$. a. $\mathrm{i} /$ fed. applied twice, at 40 days after transplanting and 21days later.

6. Hand pulling, applied twice at 55 and 75 days after transplanting.

7. Weedy check.

Herbicidal treatments were sprayed with knapsack sprayer $\mathrm{CP}_{3}$ with 200 liter water/ fed., during the two seasons. Calcium superphosphate $\left(15.5 \% \mathrm{P}_{2} \mathrm{O}_{5}\right)$ at rate of $100 \mathrm{~kg} / \mathrm{fed}$. was added before planting. Ammonium nitrate $\left(\mathrm{NH}_{4} \mathrm{NO}_{3}\right)$ and ammonium sulphate $\left(\left(\mathrm{NH}_{4}\right)_{2} \mathrm{SO}_{4}\right)$ were splitted in two equal rates and applied before the first and second irrigation. The rest agricultural practices $\mathrm{i}$ e. irrigations, pest and diseases control and others were managed in accordance with the local recommendations.

The cultivar, cabbage Brunzwick seeds were sows in soil bed on October $20^{\text {th }}$ in the two seasons. After 45 days, the seedlings were transplanted in the wire house in rows. the seedlings were transplanted at $45 \mathrm{~cm}$ within the row. Cabbage seedling were sown on one side of the row. The yields were harvested every three days from each plot area, and numbers of gathers were eleven beginning at January $25^{\text {th }}$ until at February $26^{\text {th }}$ The following data were recorded:

\section{Collected data}

\section{The following data were recorded:}

On broomrape: Prior cabbage harvesting, number of broomrape spike $/ \mathrm{m}^{2}$, weight of broomrape $\left(\mathrm{g} / \mathrm{m}^{2}\right)$, spike length $(\mathrm{cm})$ and number of capsules/spike were recorded.

\section{On cabbage yield :}

\section{Vegetative growth}

Random samples of five plants were selected from each sub plot at harvesting and separated to inner leaves (edible) and outer leaves (inedible) and the following data were recorded:

a- Number of inedible and edible leaves

b-Average fresh weight of inedible and edible leaves (g/head).

Leaf area /plant $\left(\left(\mathrm{m}^{2}\right)\right.$ : It was determined by the fresh weight method according to the method described by koller (1972) using the following formula: fresh wt. of inedible and edible leaves

Leaf area $/$ plant $(\mathrm{m} 2)=$

fresh weight of the 20 disks

$\mathrm{x}$ No. of disks x disk area.

\section{Head yield:}

Data on head yield included the weight of whole heads (outer and inner leaves and stem) of each plot expressed as ton/ fed.

\section{Head quality:}

It was determined for five plants randomly taken from each plot at harvesting. The data of head quality included:

a- Gross head weight (kg.) 
b- Perimeter of net edible head $(\mathrm{cm})$

c- Diameter of net edible head $(\mathrm{cm})$

d- Stem length (cm)

$$
\text { Head compression } \%=\frac{\text { head wt. }}{\text { head diameter }} \text { X100 }
$$

The data of all tested experiments were subjected to the statistical analysis as described Snedecor and Cochran (1980) and the least significant difference LSD at the $5 \%$ level of significance was used for the comparison among the treatments means.

\section{RESULTS AND DISCUSSION}

\section{Effect of nitrogen sources:}

On broomrape

Data presented in Table (1) show that ammonium sulfate had significant effect on the number of spikes $/ \mathrm{m}^{2}$, weight of broomrape spikes $/ \mathrm{m}^{2}$, spike length $(\mathrm{cm})$ and number of capsules/spike of broomrape parasite weed in the two seasons. Ammonium sulfate decreased these mentioned characters by $10.75,13.68$, 43.84 and $22.66 \%$, respectively in $2009 / 10$ and by 15.42, 37.26, 27.27 and $23.18 \%$, in 2010/11, respectively as compared with ammonium nitrate.

The results may be due to the death of broomrape plants under ammonium sulfate, or difficulty of penetration of the haustorium into the host root, based on lignifications, mechanical barriers formation, or inhibition of broomrape seed germination by allelochemicales substances released by cereal roots. Therefore, it decreased the above- mentioned characters of broomrape. These results are similar to that obtained by Neumann et al. (1999) and Ghalwash (2003).

Table 1. Effect of nitrogen sources on broomrape growth in 2009/10 and 2010/11 seasons.

\begin{tabular}{|c|c|c|c|c|}
\hline Nitrogen sources & $\begin{array}{c}\text { No. of } \\
\text { spikes/ } \\
\mathrm{m}^{2}\end{array}$ & $\begin{array}{c}\begin{array}{c}\text { weight } \\
\text { of spikes } \\
(\mathrm{g} / \mathrm{m})^{2} \\
2009 / 1\end{array} \\
\end{array}$ & $\begin{array}{c}\begin{array}{c}\text { spike } \\
\text { length } \\
(\mathrm{cm})\end{array} \\
\text { 0 season } \\
\end{array}$ & $\begin{array}{c}\text { No.of } \\
\text { capsules/ } \\
\text { spike }\end{array}$ \\
\hline $\begin{array}{l}\text { Ammonium nitrate } \\
(100 \mathrm{~kg} / \mathrm{fed})\end{array}$ & 21.40 & 254.00 & 14.60 & 6.40 \\
\hline $\begin{array}{l}\text { Ammonium sulphate } \\
(160 \mathrm{~kg} / \mathrm{fed})\end{array}$ & 19.10 & 219.25 & 8.20 & 4.95 \\
\hline LSD: at $5 \%$ level & 2.20 & 11.2 & 0.52 & 0.54 \\
\hline & \multicolumn{4}{|c|}{ 2010/11 season } \\
\hline $\begin{array}{l}\text { Ammonium nitrate } \\
(100 \mathrm{~kg} / \mathrm{fed})\end{array}$ & 23.35 & 583.16 & 13.20 & 7.55 \\
\hline $\begin{array}{l}\text { Ammonium sulphate } \\
\text { (160 kg /fed })\end{array}$ & 19.75 & 365.85 & 9.60 & 5.80 \\
\hline LSD: at $5 \%$ level & 3.32 & 50.76 & 1.25 & 0.30 \\
\hline
\end{tabular}

On cabbage growth, yield and its quality:

Data recorded in Table (2) show that ammonium sulphate significantly exceeded ammonium nitrate in cabbage vegetative growth in both seasons except for weight of inedible leaves and number of edible leaves in the two seasons as the differences were nonsignificant. Ammonium sulphate led to increase number of inedible, weight of edible leaves and leaf area /plant ( $\mathbf{m}^{2)}$ 6.4, 3.9 and $5.3 \%$ in the first season and 49, 1.9 and $4.6 \%$ in the second one as compared with ammonium nitrate.

Data in Table (3) show that ammonium sulphate significantly exceeded ammonium nitrate in head yield /fed in the two seasons.

Table 2. Effect of nitrogen sources on vegetative growth of cabbage in 2009/10 and 2010/11 seasons.

\begin{tabular}{|c|c|c|c|c|c|}
\hline \multirow{3}{*}{ Nitrogen sources } & \multicolumn{2}{|c|}{ Inedible leaves } & \multicolumn{2}{|c|}{ Edible leaves } & \multirow{3}{*}{$\begin{array}{c}\text { leaf } \\
\text { area/ plant }\left(\left(\mathrm{m}^{2}\right)\right.\end{array}$} \\
\hline & No. & Wt.(g) & & Wt.(g) & \\
\hline & & & \multicolumn{2}{|c|}{ 2009/10 season } & \\
\hline Ammonium nitrate (100 kg /fed) & 10.0 & 1210 & 44.6 & 1728 & 5.69 \\
\hline Ammonium sulphate $(160 \mathrm{~kg} / \mathrm{fed})$ & 9.4 & 1281 & 43.9 & 1799 & 6.01 \\
\hline \multirow[t]{2}{*}{ LSD: at $5 \%$ level } & 0.45 & NS & NS & 45.34 & 0.35 \\
\hline & \multicolumn{5}{|c|}{ 2010/11 season } \\
\hline $\begin{array}{l}\text { Ammonium nitrate }(100 \mathrm{~kg} \\
\text { /fed) }\end{array}$ & 10.0 & 1141 & 42.7 & 1754 & 6.2 \\
\hline $\begin{array}{l}\text { Ammonium sulphate }(160 \mathrm{~kg} \\
\text { /fed) }\end{array}$ & 6.7 & 1180 & 40.3 & 1788 & 6.5 \\
\hline LSD: at $5 \%$ level & 0.61 & NS & NS & 40.34 & 0.23 \\
\hline
\end{tabular}

Table 3. Effect of nitrogen sources on head yield and its quality 2009/10 and 2010/11 seasons.

Cabbage yield and head quality

2009/10 season

\begin{tabular}{lcccccc} 
Nitrogen sources & $\begin{array}{c}\text { Gross } \\
\text { Wt. }(\mathbf{k g})\end{array}$ & $\begin{array}{c}\text { Perimeter } \\
(\mathbf{c m})\end{array}$ & $\begin{array}{c}\text { Diameter } \\
(\mathbf{c m})\end{array}$ & Yield ton/fed. & $\begin{array}{c}\text { Stem } \\
\text { length } \\
(\mathbf{c m})\end{array}$ & $\begin{array}{c}\text { Head } \\
\text { Compression\% }\end{array}$ \\
\hline Ammonium nitrate (100 kg /fed) & 5.25 & 86.05 & 24.80 & 46.87 & 12.9 & 20.15 \\
Ammonium sulphate (160 kg /fed) & 6.25 & 91.10 & 32.05 & 50.58 & 11.6 & 22.67 \\
LSD: at 5\% level & 0.52 & 2.32 & 3.10 & 1.93 & 1.09 & 2.70 \\
& & \multicolumn{2}{c}{$2010 / 11$ season } & 49.38 & 14.15 & 20.99 \\
Ammonium nitrate (100 kg /fed) & 5.30 & 62.75 & 25.95 & 52.78 & 13.30 & 22.49 \\
Ammonium sulphate (160 kg /fed) & 6.58 & 79.20 & 33.00 & 1.96 & 0.66 & 1.30 \\
LSD: at 5\% level & 1.99 & 2.02 & 4.47 & & &
\end{tabular}

Head quality of gross weight $(\mathrm{kg})$, perimeter $(\mathrm{cm})$ and diameter $(\mathrm{cm})$ of cabbage from ammonium sulphate were higher (16, 5.5 and $22.6 \%)$ and $(19.5$, 20.8 and $21.4 \%$ ), in first and second seasons, respectively than ammonium nitrate. These results are similar to those reported by Ghalwash (2003).

Additionally, data in Table (3) show also that ammonium sulphate significantly exceeded ammonium 
nitrate in head quality (stem length, $\mathrm{cm}$ and head compression\%) in both seasons. Ammonium sulphate recorded increased by, 11.2 and $11.1 \%$ and 6.4, 6.7 \%, respectively as compared with ammonium nitrate in the two seasons. These results are similar to those reported by Ghalwash et al. (2008).

\section{Effect of herbicides:}

On broomrape growth :

Data presented in Table (4) indicate that all broomrape control treatments decreased significantly number of spikes/ $\mathrm{m}^{2}$, weight of spikes/ $\mathrm{m}^{2}$, spike length $(\mathrm{cm})$ and number of capsules/spike of broomrape parasite weed in both seasons.

Spraying glyphosate and Imazapic, twice, efficiently decreased number of broomrape spikes/ $\mathrm{m}^{2}$ by 66.78 and $65.04 \%$; weight of spikes/ $\mathrm{m}^{2}$ by 59.67 and $60.82 \%$; broomrape spike length by 42.65 and $43.39 \%$; and number of capsules/spike by 68.75 and $67.67 \%$, respectively, in 2009/10 season and by 65.90 and 65.56\%; 75.65 and $76.08 \%$; and 42.54 and $40.19 \%$ and 62.75 and $62.07 \%$, respectively, in 2010/11 season, followed by hand pulling (twice) in two seasons.

\begin{tabular}{|c|c|c|c|c|}
\hline Table 4, $\begin{array}{c}\text { Effect o } \\
\text { broomra } \\
\text { and2010 }\end{array}$ & $\begin{array}{l}\text { of he } \\
\text { ape } \\
/ 11 \mathrm{se}\end{array}$ & $\begin{array}{l}\text { rbicides } \\
\text { growth } \\
\text { asons. }\end{array}$ & $\begin{array}{c}\text { treat } \\
\text { in }\end{array}$ & $\begin{array}{c}\text { ents on } \\
2009 / 10\end{array}$ \\
\hline Herbicides treatments & $\begin{array}{c}\text { No. } \\
\text { of } \\
\text { spikes } \\
/ \mathbf{m}^{2}\end{array}$ & $\begin{array}{c}\text { Wt. of } \\
\text { spike (g/ } \\
\left.\mathbf{m}^{2}\right)\end{array}$ & $\begin{array}{c}\text { spike } \\
\text { length } \\
(\mathrm{cm})\end{array}$ & $\begin{array}{c}\text { No .of } \\
\text { capsules }\end{array}$ \\
\hline & & 2005 & 10 seaso & \\
\hline Pendimethalin750ga.i. /fed. & 25.88 & 285.0 & 12.38 & 4.88 \\
\hline Glyphosate(36g/a.i/fed) (twice) & 12.00 & 153.8 & 9.25 & 3.75 \\
\hline Imazapic(20g/a.i/fed) (twice) & 12.63 & 149.4 & 9.13 & 3.88 \\
\hline Hand pulling (twice) & 14.63 & 213.8 & 10.13 & 3.88 \\
\hline Control (weedy check) & 36.13 & 381.3 & 16.13 & 12.00 \\
\hline $\begin{array}{l}\text { LSD: at } 5 \% \text { level } \\
2010 / 11 \text { season }\end{array}$ & 3.25 & 42.38 & 1.55 & 1.37 \\
\hline Pendimethalin750ga.i. /fed. & 28.63 & 659.3 & 12.13 & 5.50 \\
\hline Glyphosate (36 g/a.i/fed) (twice) & 13.00 & 234.8 & 9.25 & 4.89 \\
\hline Imazapic(20g/a.i/fed) (twice) & 13.13 & 230.6 & 9.63 & 4.98 \\
\hline Hand pulling (twice) & 14.88 & 274.9 & 9.89 & 5.00 \\
\hline Control (weedy check) & 38.13 & 964.3 & 16.10 & 13.13 \\
\hline LSD: at $5 \%$ level & 2.35 & 86.25 & 1.32 & 1.03 \\
\hline
\end{tabular}

These results are in agreement with those of Americanos et al. (1995) Ghalwash (2003) and Ismail, (2013). who reported that the action of glyphosate on broomrape is attributable to its selective accumulation in the young parasite plant up to a level four times as high as that in faba bean host root three days after spraying

On cabbage growth, yield and its quality:

Data presented in Table (5) indicate that all herbicides treatments as well as hand pulling (twice) increased number and weight of inedible leaves, edible leaves and leaf area /plant $\left(\mathrm{m}^{2}\right)$ in the two seasons.

Herbicidal treatments except pendimethalin gave the heighest values as the increases in weight of edible leaves over control were $79.52,68.59$, and $68.15 \%$, for glyphosate, twice, imazapic, twice and hand pulling, twice in season 2009/10, respectively and 82.36, 63.29 and $69.62 \%$ in season $2010 / 11$, respectively from the same treatments. In regard to leaf area/plant $\left(\mathrm{m}^{2}\right)$, the results were similar in both seasons. In first season, glyphosate, imazapic and hand pulling (twice) increased this parameter by 19.62, 12.71 and $13.83 \%$, respectively and by $31.93,21.61$ and $27.72 \%$ over weedy check in the second season, respectively.

Table 5. Effect of herbicides treatments on cabbage growth in 2009/10 and 2010/11 seasons

\begin{tabular}{|c|c|c|c|c|c|}
\hline \multirow[t]{3}{*}{ Herbicides treatments } & \multicolumn{2}{|c|}{$\begin{array}{c}\text { Inedible } \\
\text { leaves }\end{array}$} & \multicolumn{2}{|c|}{ Edible leaves } & \multirow{3}{*}{$\begin{array}{c}\text { Leaf } \\
\text { area/ } \\
\text { plant }\left(\left(\mathbf{m}^{2}\right)\right.\end{array}$} \\
\hline & No. & Wt.(g) & No. & Wt.(g) & \\
\hline & \multicolumn{4}{|c|}{$2009 / 10$ season } & \\
\hline Pendimethalin $750 \mathrm{~g}$ a. i. /fed. & 8.50 & 1394.4 & 42.88 & 1639.4 & 5.36 \\
\hline Glyphosate (36g/a.i/f) (twice) & 10.50 & 1391.6 & 44.38 & 2091.4 & 6.40 \\
\hline Imazapic (20 g/a.i/f) (twice) & 11.00 & 1303.9 & 45.88 & 1963.9 & 6.03 \\
\hline Hand pulling (twice) & 11.00 & 1315.0 & 46.5 & 1959.0 & 6.09 \\
\hline Control (weedy check) & 7.50 & 911.50 & 41.38 & 1165.0 & 5.35 \\
\hline \multirow[t]{2}{*}{ LSD: at $5 \%$ level } & 0.90 & 67.79 & 1.19 & 104.24 & 0.40 \\
\hline & \multicolumn{5}{|c|}{ 2010/11season } \\
\hline Pendimethalin750ga. i. /fed. & 7.75 & 1186.3 & 41.38 & 1485.0 & 5.60 \\
\hline Glyphosate $(36 \mathrm{~g} / \mathrm{a} . \mathrm{i} / \mathrm{f})$ (twice) & 8.63 & 1298.8 & 44.89 & 2183.9 & 6.90 \\
\hline Imazapic (20 g/a.i/f) (twice) & 9.63 & 1228.8 & 43.50 & 1955.0 & 6.36 \\
\hline Hand pulling (twice) & 8.75 & 1238.9 & 43.75 & 2031.3 & 6.68 \\
\hline Control (weedy check) & 7.00 & 848.8 & 33.89 & 1197.5 & 5.23 \\
\hline LSD: at $5 \%$ level & 0.97 & 74.41 & 2.07 & 98.94 & 0.34 \\
\hline
\end{tabular}

It is clear from Table (6) that the herbicides treatments beside hand pulling increased significantly the gross head weight of cabbage, perimeter and diameter of the head / plant in both seasons. However, imazapic, glyphosate and hand pulling (twice) gave the best results as the gross weight of the head was increased by $64.4,64.4$ and $61.1 \%$ in the first season

Table 6. Effect of herbicides treatments on cabbage
yields and its quality in 2009/10 and 2010/11 seasons

\begin{tabular}{|c|c|c|c|c|c|c|}
\hline Herbicides treatments & $\begin{array}{c}\text { Gross } \\
\text { weight } \\
\text { (kg) }\end{array}$ & $\begin{array}{c}\text { Peri } \\
\text { meter } \\
(\mathbf{c m})\end{array}$ & $\begin{array}{c}\text { Diam } \\
\text { eter } \\
(\mathrm{cm})\end{array}$ & $\begin{array}{c}\text { Stem } \\
\text { length } \\
(\mathrm{cm})\end{array}$ & $\begin{array}{c}\text { Head } \\
\text { Compr } \\
\text { ession } \\
(\%)\end{array}$ & $\underset{\substack{\text { yield } \\
\text { (ton/fed) }}}{\text {. }}$ \\
\hline & \multicolumn{6}{|c|}{$2009 / 10$ season } \\
\hline Pendimethalin750ga.i. fed. & 5.88 & 89.63 & 27.63 & 12.88 & 19.34 & $45 . .66$ \\
\hline Glyphosate(36g/a.i/f) twice) & 6.38 & 99.13 & 30.75 & 11.88 & 20.71 & 55.19 \\
\hline $\operatorname{Imazapic}(20 \mathrm{~g} / \mathrm{a} . \mathrm{i} / \mathrm{f})$ (twice) & 6.38 & 95.88 & 30.75 & 12.63 & 21.18 & 59.21 \\
\hline Hand pulling (twice) & 6.25 & 87.50 & 33.13 & 11.25 & 21.15 & 51.68 \\
\hline Control (weedy check) & 3.88 & 70.75 & $19 . .38$ & 15.75 & 16.66 & 31.87 \\
\hline \multirow[t]{2}{*}{ LSD: at $5 \%$ level } & 0.89 & 2.85 & 2.58 & 1.07 & 1.90 & 2.28 \\
\hline & \multicolumn{6}{|c|}{ 2010/11season } \\
\hline Pendimethalin750ga.i. /fed. & 6.18 & 74.63 & 30.50 & 13.25 & 20.78 & 49.88 \\
\hline Glyphosate(36g/a.i/f) twice) & 6.25 & 78.63 & 33.63 & 12.50 & 22.93 & 55.35 \\
\hline $\operatorname{Imazapic}(20 \mathrm{~g} / \mathrm{a} . \mathrm{i} / \mathrm{f})$ (twice) & 6.07 & 72.25 & 32.38 & 13.63 & 21.95 & $59 . .51$ \\
\hline Hand pulling (twice) & 6.25 & 74.13 & 29.75 & 13.50 & 21.29 & 53.68 \\
\hline Control (weedy check) & 3.56 & 55.25 & 20.87 & 15.75 & 15.75 & 35.98 \\
\hline LSD: at $5 \%$ level & 0.48 & 2.35 & 4.53 & 1.09 & 2.30 & 3.03 \\
\hline
\end{tabular}

Likewise, glyphosate, imazapic and hand pulling (twice), increased significantly the perimeter and diameter of the head by $40.11,35.52$ and $23.67 \%$ and $58.67,58.67$ and $70.95 \%$ in the first season and by $42.31,30.77$ and $34.17 \%$ and $61.14,55.15$ and $42.55 \%$ over the weedy check in second one, respectively.

Data give in Table (6) demonstrate that pendimethalin, glyphosate, imazapic, and hand pulling treatments decreased the stem length by $18.22,24.57$, 19.80 and $28.57 \%$ compared with weedy check in the first season and by 15.87, 20.63, 13.46 and $14.28 \%$ from these treatments in second one. 
For head compression \%, the results obtained were similar in both seasons. Thus, imazapic, glyphosate, hand pulling and pendimethalin treatments increased its parameter by $27.13,24.30,26.95$ and $16.08 \%$ in first season and by $39.36,45.78,35.17$ and $31.93 \%$ in the second one in a decreasing order .

Imazapic gave the largest cabbage yield (ton/fed) followed by glyphosate and hand pulling in both seasons. These treatments gave rise to increased yield by $85.78,73.17$ and $62.15 \%$, in the first season and by $65.40,53.83$ and $49.19 \%$, respectively, in second one, as compared with weedy check. It is worthwhile to mention that, these treatments which gave the highest values of cabbage yield also gave the lowest numbers of broomrape spikes/ $\mathrm{m}^{2}$ and capsules per spike and the smallest weight of spikes These results are similar to those reported by Ghalwash et al. (2008) and Ismail, (2013).

\section{Interaction between $\mathbf{N}$ sources and herbicides} treatments:

Results presented in Table (7) show that spike length $(\mathrm{cm})$, yield (ton/fed.) in both seasons and weight of edible leaves ( $\mathrm{g} /$ plant) in 2009/10 season and weight of spikes $/ \mathrm{m}^{2}$ in 2010/11 season were highly significant affected by the interaction between $\mathrm{N}$ sources and herbicides treatments, while the remainder parameters for both broomrape and cabbage were not appreciably affected by the interaction. Therefore, the nonsignificant results were not included in the table.

Table (7): Effect of the interaction between $N$ sources and herbicides treatments on broomrape and cabbage yield in 2009/10 and 2010/11 seasons

\begin{tabular}{|c|c|c|c|c|c|c|c|}
\hline \multirow{2}{*}{ 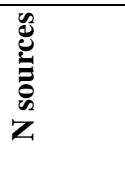 } & \multirow[b]{2}{*}{ Herbicides treatments } & \multicolumn{3}{|c|}{ 2009/10 season } & \multicolumn{3}{|c|}{ 2010/11 season } \\
\hline & & $\begin{array}{c}\text { Spike } \\
\text { length } \\
\text { (cm) }\end{array}$ & $\begin{array}{c}\text { Weight } \\
\text { of edible } \\
\text { leaves(g } \\
\text { / plant) }\end{array}$ & $\begin{array}{c}\text { Yield } \\
\text { (ton/fed.) }\end{array}$ & $\begin{array}{c}\text { Spike } \\
\text { length } \\
(\mathrm{cm})\end{array}$ & $\begin{array}{c}\text { Weight } \\
\text { of } \\
\text { spikes } \\
(\mathrm{g} / \mathrm{m})^{2}\end{array}$ & $\begin{array}{c}\text { Yield } \\
\text { (ton/fed.) }\end{array}$ \\
\hline \multirow{5}{*}{ 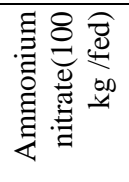 } & Pendimethalin $750 \mathrm{~g}$ a. i. /fed. & 8.25 & 1496 & 43.11 & 10 & 593.5 & 49.79 \\
\hline & Glyphosate (36 g/a.i/f) (twice) & 4.75 & 2110 & 51.55 & 6.5 & 189.5 & 59.49 \\
\hline & Imazapic (20 g/a.i/f) (twice) & 6.50 & 1937 & 49.75 & 8.25 & 163.0 & $56 . .20$ \\
\hline & Hand pulling (twice) & 5.50 & 1930 & 58.80 & 6.75 & 226.0 & 45.75 \\
\hline & Control (weedy check) & 16.00 & 1167 & 31.12 & 16.5 & 639.8 & 35.64 \\
\hline \multirow{5}{*}{ 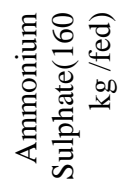 } & Pendimethalin $750 \mathrm{~g}$ a. i. /fed. & 16.50 & 1782 & 48.21 & 14.25 & 725.0 & $49 . .97$ \\
\hline & Glyphosate (36 g/a.i/f) (twice) & 13.75 & 2072 & 58.82 & 13.25 & 280.0 & $59 . .51$ \\
\hline & Imazapic (20 g/a.i/f) (twice) & 13.75 & 1990 & 53.62 & 11.00 & 298.3 & $56 . .50$ \\
\hline & Hand pulling (twice) & 12.75 & 1987 & 59.63 & 11.75 & 323.8 & $61 . .59$ \\
\hline & Control (weedy check) & 16.25 & 1162 & 32.62 & 15.75 & 1289 & 36.30 \\
\hline \multicolumn{2}{|c|}{ LSD: at $5 \%$ level } & 2.20 & 1.47 & 0.32 & 1.87 & 122.0 & 0.43 \\
\hline
\end{tabular}

The great reduction for above-mentioned characters were obtained by the interaction between ammonium sulfate with herbicides treatments as compared with ammonium nitrate with the same herbicides treatments. The combined interaction between ammonium sulphate with glyphosate gave the largest cabbage yield (ton /fed) while, the lowest one was obtained from ammonium nitrate with weed check treatment in the two seasons.

Therefore, the best cabbage yield was 51.55 and 59.49 ton/fed after obtained by the combined interaction between ammonium sulphate with glyphosate (twice) in 2009/10 and 2010/11 seasons, respectively, followed by imazapic twice, while, the lowest yield $(32.62,36.31$ ton/fed), were after the interaction between ammonium nitrate with weedy check treatment in both seasons.

\section{REFERENCES}

Al-Rahban, B., N. Al-Hussein and A.F. Abied. (2009). Chemical control of two Orobanche species $(O$. crenata and O.aegeptiaca) which attack lentil crop in Syria. Arab Journal of plant.

Americanos, P.G. and N.A. Vouzounis (1995). Control of Orobanche in cabbage. Technical Bulletin 170 isso 0070-2315 Agricultural Research Institute Ministry of Ariculture, natural resouces and the environment, Protection, 27: 152-158.
Black, C.D.; D.D. Evans: L . E. Ensminger; J .L. White and F. E Clark, (1965) Methods of soil Analysis. Part I and Part II. Amer. Soc. Agron. Inc. Publisher, Madison -Wisconsin, U.S.A.

Caruso, G.; Stoffella P.J.; Cantliffe D.J. and Damato G.(2000). Relationships among planting time, chemical weed control and weed cover in cabbage (Brassica oleracea L. var. capitata). $8^{\text {th }}$ rnational Symposium on Timing of Field Production in Vegetable Crops, Bari, Italy, 15-18 October, 1997. Acta -Horticulturac., No. 533, 229-241.

Curran W. S.; Mcglamery M. D.; Lieble R.A. and Lingenfelter D. D. ( 2014) Adjuvants for ehancing herbicide performance. Penn State Extension College of Agricultural Sciences extension. Pus. Edu /pests/ weed /control, Agronomy facts 37.

Dhiman, N. K.; Nandal T.R. and Rajender S. (2005). Effect of herbicides and their combinations on economics of cabbage production. CropResearch- Hisar. 30 (1): 73-76.

Dixit, A.J.; Ramteke J.R.; Thorat. S.T. and Jambhale N.D. (2005). Efficacy of herbicides in controlling weeds in cabbage. Journal-ofMaharashtra-Agricultural Universities. 30(3): 362-363. 
Etagegnehu, G. M. and Rungsit, S. K. J. (2004). Effect of nitrogen fertilizers on branched broomrape (Orobanche ramosa L.) in tomato (Lycopersicon esculentum Mill.) Nat. Sci.) 38:311-319.

Garcia-Torres L., M. Castejon-Mun`oz, F. LopezGranados, and M. Jurado- Exposito. (1995). Imazapyr applied postemergence in sunflower (Helianthus nnuus) for broomrape (Orobanche cernua) control. Weed Technol. 9:819-824.

Ghalwash, A. M. and Manal A. Abd Alla ( 2008). Effect of weed control on growth, productivity and quality of cabbage (Brassica oleracea var capitata ) Egypt. J. Agric. Res., 86 (1) : 365-381.

Ghalwash, A. M. (2003). Studies on broomrape weed in Egypt. Ph.D. Thesis, Fac. Agric. Minufiya Univ., Egypt.

Ismail, A.E.A. (2013) Integration between nitrogen, manure fertilizers cultural practices and glyphosate on broomrape ( orobanche crenata Forsk) control in faba beans (Vicia faba L.). Bull. Fac. Agric, Cairo Univ. 64: 369-378.

Jackson, M.L.( 1967). Soil Chemical Analysis. Prentice Hall Private, Ltd., New York.
John, D. Nalewaja Alewaga and Robert Matysiak (1992) Species differ in response to adjuvant with glyhosatel. Weed Technology, Vol. 6, No. 3, pp. 561-566.

Koller, H. R. (1972) Leaf area - leaf weight relation ship in soybean Canopy . Crop Sci., 12:180-183.

Neumann, U. ; Vian, B.; Weber, H.C. and Salle G. (1999) Interface between haustoria of parasitic members of the scrophulariaceae and their hosts: a histochemical and immunocytochemical approach. Protoplasma, 207: 84-97.

Semidey, N.; Gonzalez A. and Aponte A. (1999). Application timing for clomazone and oxyfluorfen in transplanted cabbage. Journal of Agriculture of the University of Puerto Rico. 83: 3-4, 175-180.

Snedecor, D.W. and Cochran W. (1980). Statistical Methods, seven th ed., Iowa state University Press ,Iowa U.S.A.

Sonnenberg, P. E. and Silva N. F. (2005). Weed interference in transplanted cabbage. Pesquisa Agropecuaria Tropical. 35(1): 9-11.

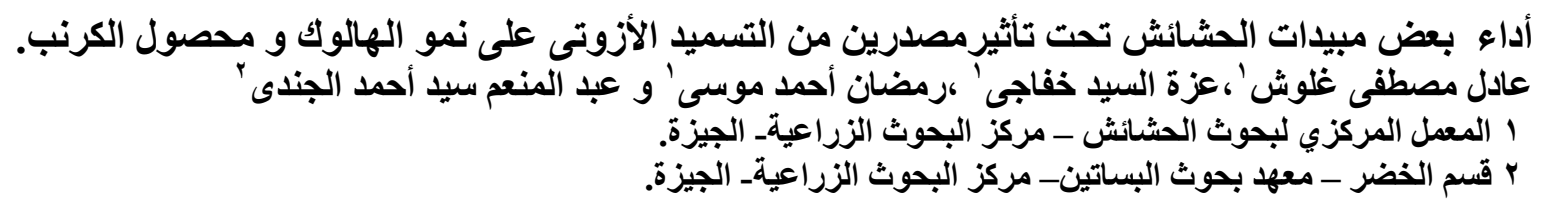

أجريت تجربتان حقليتان للكرنب بالصوبة السلكية بمعمل الحثائش بمحطة البحوث الزراعية بسخا محافظة كفر الثيخ خلال

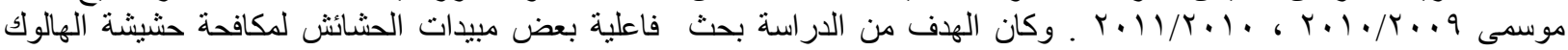

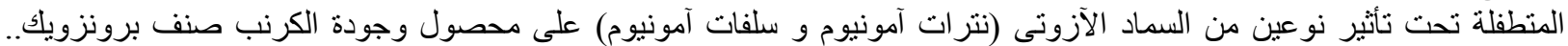

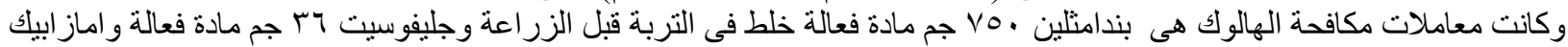

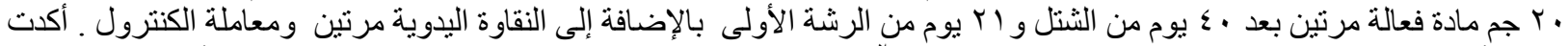

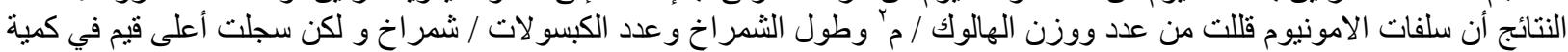

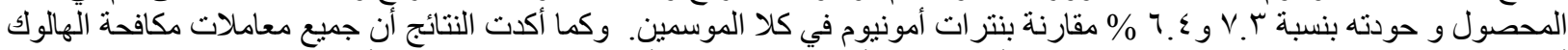

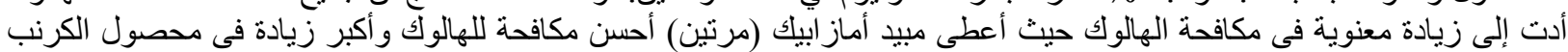

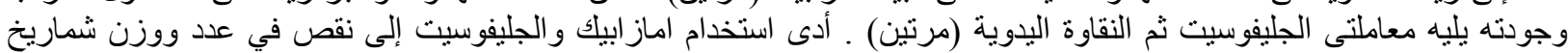

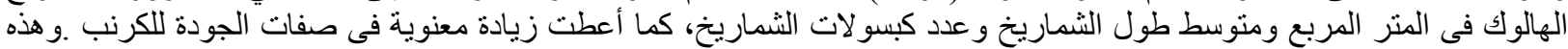

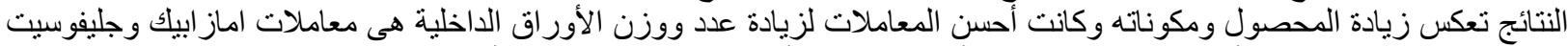

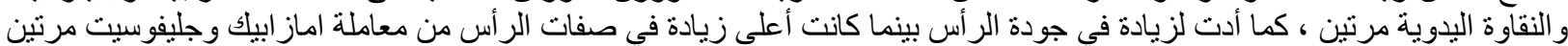

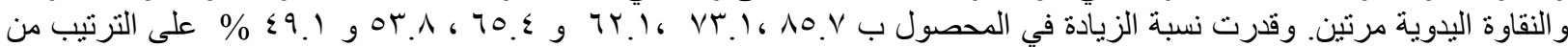

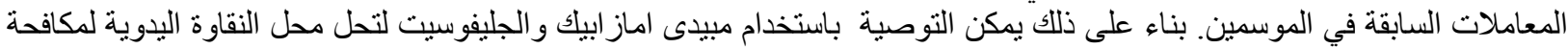
الهالوك وزيادة إنتاجية وجودة الموني محصول الكرنب. 